\title{
Chemical characterization of the antioxidant, antihyperglycemic and antihypertensive capacities of red rice (Oryza sativa L.) whole flour
}

\section{Caracteristicas físico-químicas, capacidad antioxidante, anti-hiperlucémica y antihipertensiva de la harina de arroz rojo (Oryza sativa L.)}

\begin{abstract}
Oryza sativa $L$. rice has large amounts of proteins and minerals, besides presenting several pigmented varieties. Red rice is distinguishable due to its great nutritional value compared to the regular white variety. Its red pericarp pigmentation is due to the bioactive compounds that are responsible for its health benefits. The objective of this study was to evaluate the physical-chemical characterization, antioxidant, antihyperglycemic and antihypertensive capacity of flours of three different red rice cultures (Rubi, Virgínia and Pequeno). All samples presented specific levels of carbohydrates for cereals with low fat content and excellent levels of protein and resistant starch. In addition, the samples had a high antioxidant, antihyperglycemic and antihypertensive capacity. Antihyperglycemic capacities were measured as percent inhibition for amylase (56.7$76.5 \%)$ and glycosidase (81.0-76.6\%), respectively, and antihypertensive capacity as the percentage inhibition of the angiotensin converting enzyme (38.4-34.7\%). In addition, Pequeno flour presented the best results for antioxidant and antihyperglycemic capacity in comparison to the two flours tested. Thus, all red rice flours can be a source of functional compounds when added to food.

Key Words: Angiotensin; Antidiabetic; Cereals; Proanthocyanidin; Starch.
\end{abstract}

\section{RESUMEN}

El arroz integral (Oryza sativa L.) posee importantes cantidades de proteínas, vitaminas, minerales y fitoquímicos. El arroz rojo se destaca por su gran valor nutricional. La pigmentación roja del pericarpio está asociado al contenido de compuestos bioactivos, que están directamente relacionados a los beneficios de salud humana.Teniendo en cuenta lo antes expuesto se propuso evaluar las caracteristicas físico-químicas, capacidad antioxidante, antihiperglucémica y antihipertensiva de las harinas de tres diferentes cultivos de arroz rojo (Rubí, Virginia y Pequeño). Todas las muestras presentaron niveles específicos de carbohidratos para cereales con bajo contenido de grasa y altos contenidos de proteína y almidón resistente. Además, las muestras presentaron una alta capacidad antioxidante,
Andréa dos Anjos Silva ${ }^{1 *}$, Marcus Vinicius da Silva Ferreira ${ }^{1}$, Rafael Hydalgo Passeri Lima², José Lucena Barbosa Junior ${ }^{1}$, Luiz Beja Moreira Moreira², Maria Ivone Martins Jacintho Barbosa'.

1. Federal Rural University of Rio de Janeiro (UFRRJ), Institute of Techonolgy (IT), Department of Food Technology, Institute of Technology, Seropédica, RJ, Brazil.

2. Federal Rural University of Rio de Janeiro (UFRRJ), Institute of Agronomy (IA), Department of Phytotechny, Seropédica, Rio de Janeiro, Brazil.

*Corresponding author: Andrea Silva. Federal Rural University of Rio de Janeiro (UFRRJ), Institute of Techonolgy (IT), Department of Food Technology, BR 465,Km. 7 - Seropédica - RJ, Brazil - CEP: 23890-000 Contacto: (21) 2682-1023. E-mail: anjosnutri@gmail.com.

Este trabajo fue recibido el 25 de mayo de 2019. Aceptado con modificaciones: 23 de septiembre de 2019. Aceptado para ser publicado: 10 de octubre de 2019.

anti-hiperglucémica y antihipertensiva. La capacidad antihiperglicémica se midió en porcentaje de inhibidores de $\alpha$-amilasa (56.7-76.5\%) y $\alpha$-glucosidasa (81.0-76.6\%), respectivamente; y capacidad antihipertensiva como el porcentaje de inhibición de la enzima convertidora de la angiotensina (38.4-34.7\%). El cultivar Pequeño presentó mayor capacidad antioxidante y anti-hiperglucémica en comparación a los demás cultivares. Así, todas las harinas de arroz rojo pueden ser vehículos de compuestos funcionales en los alimentos.

Palabras clave: Angiotensina; Antidiabético; Almidón; Cereales; Proantocianidinas. 


\section{INTRODUCTION}

Oryza sativa L. rice is one of the most important cereals in the world economy, of which China and India are ranked as the major producers. Carbohydrates represent a major component of this cereal, an important proportion of plant protein, as well as minerals, such as potassium, magnesium, and zinc ${ }^{1}$.

Among many varieties, whole grain red rice has high levels of non-starch polysaccharides (NSP) that are present in the grain caryopsis, among other bioactive compounds, such as phenolics. These grains are associated with the reduction of chronic conditions, such as dyslipidemia, type II diabetes and cardiovascular diseases, and can even prevent cancer ${ }^{2}$.

The most used cereal in the pasta industry is wheat, due to its technological characteristics. However, this cereal presents high energetic value, low nutritional profile (micronutrients and bioactives) and has a high allergy response. Therefore, it is necessary to combine wheat flour with other sources that have bioactive compounds, such as phenolics with antioxidant capacity that can enhance the glycemic, antioxidant and hypertensive response in those products ${ }^{3}$.

Rice is usually consumed after cooking. However, there has been a constant increase for new processes and products from this cereal in its original form. In its raw form it has many functional values due to its bioactive compounds that confer its color. Furthermore, this cereal is hypoallergenic, gluten-free and flavorless. Thus, the production of red rice flour has increased. Manufacturing cost is low and the flour can be used in the making of bread and pasta because of the technological, nutritional and functional characteristics ${ }^{4}$.

Despite the potential of this cereal in the pasta industry, studies regarding the chemical composition are still scarce. Studies have been limited to the evaluation of bioactive compounds of the flour obtained from pigmented rice cultivars ${ }^{5}$.

Therefore, the objective of this study was to evaluate the chemical characteristics, chromatic parameters, antioxidant capacity, antihyperglycemic, and antihypertensive properties, of three Brazilians red rice cultivars.

\section{MATERIAL AND METHODS}

Three cultivars (Rubi, Virginia, and Pequeno) of red rice (Oryza sativa L.) were assigned by the Institute of Agronomy of the Federal Rural University of Rio de Janeiro (UFRRJ) (located at latitude coordinates-22.764596 and longitude-43.688343), manually harvested after 120 days of seeding at around $20 \%$ wet basis and submitted to sun drying until they reached $13.0 \%$ wet basis. After drying, the grains had their peel removed in order to obtain grains of a whole-grain subclass. Three kgs of each samples were ground in a LM3100 hammer mill (Perten Instruments AB, Huddinge, Sweden) equipped with a $0.8 \mathrm{~mm}$ aperture sieve (250 mesh) and then stored in hermetically sealed pots for further analysis.

\section{Physicochemical characterization}

The quantification of protein (kjeldahl method), lipids (SOXLET method), and ash were evaluated according to the Association of Official Analytical Chemists ${ }^{6}$, while total carbohydrates and non-starch polysaccharides (as described next) were calculated by difference based on the other components (lipds, protein, moisture and ashes). The cultivars were scanned and photographed using a Epson ${ }^{\circledR}$ perfection model (124OU) scanner and a Canon ${ }^{\circledR}$ EOS R camera to show their starch content and grain structure (Figure 1).

\section{Determination of total, resistant and digestible starch}

Starch content was determined by acid hydrolysis, followed by Lane \& Enyon quantification ${ }^{6}$. The resistant starch (RS) content quantification was performed following an adapted methodology, where glucose was determined by Lane \& Enyon $^{6}$, using pancreatin, $\alpha$-amylase and amyloglucosidase. Digestible starch was calculated according to $\mathrm{Frei}^{7}$ as the difference between total and RS.

\section{Amylose and amylopectin content and color parameters}

Amylose and amylopectin content were performed using the 3.MZ.K-AMYL kit (ROMER Labs $\left.{ }^{\circledR}\right)$, where the results were expressed in percentage. The chromatic parameters

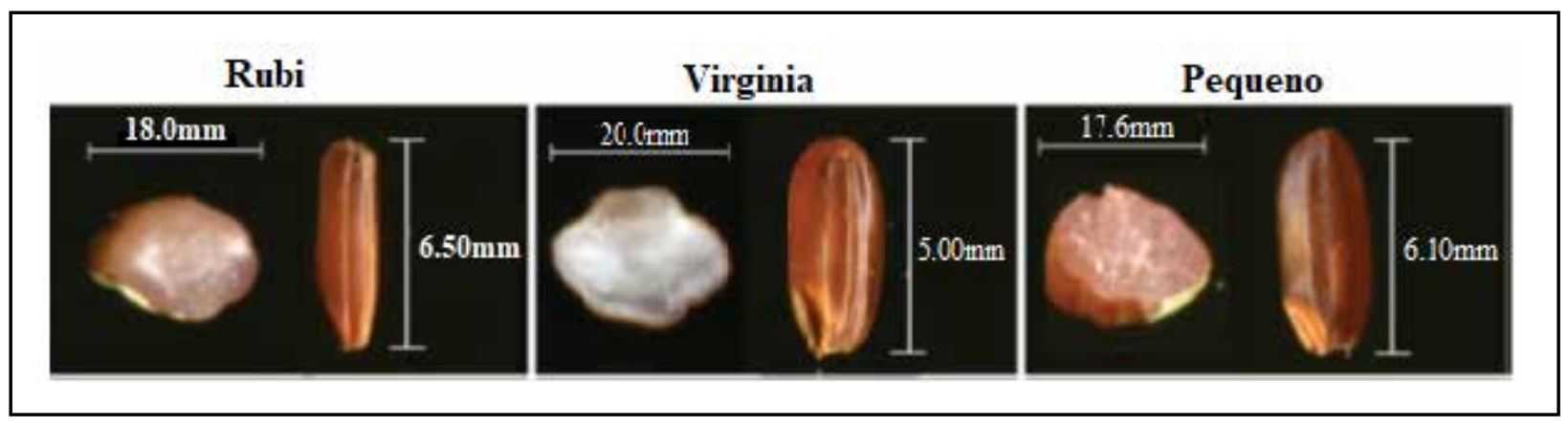

Figure 1: Red grain scanned (tranversal cut) and camera picture (longitudinal) images for the three cultivars. 
of the samples were evaluated in triplicate (in different areas of each sample) using a Hunter Lab Miniscan EZ ${ }^{\circledR}$ portable colorimeter.

\section{Antioxidant capacity Free radical scavenger method}

Determination of total antioxidant capacity was performed by scavenging 2,2-definil-1-picrylhydrazine (DPPH) according to Rufino et al. ${ }^{8}$ using (ethanolic:water, $80: 20 \mathrm{v} / \mathrm{v}$ ) aqueous extracts. Radical scavenger activity was calculated, where the absorbance values $(517 \mathrm{~nm}$ ) of the sample and the blank were used after 60 minutes of reaction. Antioxidant capacity values were expressed in $\mu \mathrm{M}$ Trolox $/ 100 \mathrm{~g} \mathrm{~g}^{-1}$ and results were expressed in dry weight.

\section{Ferric Reducing Antioxidant Power method (FRAP)}

Antioxidant capacity using the Ferric Antioxidant Reducer (FRAP) method was performed according to Rufino et al. ${ }^{8}$ with $80 \%$ ethanol extracts. The FRAP solution was prepared using a solution of 2,4,6-tris (2-pyridyl) -s-triazine (TPTZ), acetate buffer and ferric chloride. All readings were performed at $595 \mathrm{~nm}$. To calculate antioxidant capacity, values were subject to a standard curve. Results were expressed in $\mu \mathrm{M}$ Trolox 100 g.g ${ }^{-1}$ of dried sample.

\section{Determination of total phenolic content (TPC)}

To determine the total phenolic compound content of samples, methods described by Rufino et al. ${ }^{8}$ were used, using Folin-Ciocalteu phenolic reagent in aqueous extracts. The results were plotted in a curve which used gallic acid as the standard, with the mean absorbance $(725 \mathrm{~nm})$ to express the results in mg of gallic acid per gram of sample (mg of GAE. $\mathrm{g}^{-1}$ of the dried sample).

\section{Determination of proanthocyanidins}

Proanthocyanidins determination was performed according to Chen McClung and Bergman ${ }^{9}$, with 0.500 extract and $80.0 \%$ ethanol followed by the addition of butanol-HCL reagent and ferric reagent previously prepared. The tubes were then placed in a heating block at $100{ }^{\circ} \mathrm{C}$ for $60 \mathrm{~min}$. After cooling, the preparation was measured at $550 \mathrm{~nm}$ using the unheated mixture as a blank.

\section{Determination of antihyperglycemic capacity Inhibition activity of $\alpha$-amylase}

The evaluation of the inhibition activity of $\alpha$-amylase was performed according to Lavelli et al. ${ }^{10}$ with modifications in the number of enzymatic aliquots. Initially, $\alpha$-amylase and starch were mixed with phosphate buffer (pH 6,8). $100 \mu \mathrm{L}$ solution of $\alpha$-amylase $\left(20.0\right.$ units $\left.\mathrm{mL}^{-1}\right)$ was added to $100 \mu \mathrm{L}$ of extract (sample) in test tubes at $37{ }^{\circ} \mathrm{C}$ for $5 \mathrm{~min}$. The reaction was initiated by adding $250 \mu \mathrm{L}$ of a starch solution (10.0 $\left.\mathrm{g} \mathrm{L}^{-1}\right)$. To obtain the blank and control the enzyme and then the sample was removed. After the addition of 250 $\mu \mathrm{L}$ of dinitrosalicylic acid, the tube was heated to $100{ }^{\circ} \mathrm{C}$ and held for $15 \mathrm{~min}$. Afterward, $2 \mathrm{~mL}$ of distilled water was added and the absorbance was read at $540 \mathrm{~nm}$ using a spectrophotometer (Kasuaki, Nova Model 2000 uv, China).

\section{The inhibition activity of $\alpha$-glucosidase}

The $\alpha$-glucosidase inhibition was performed according to Lavelli ${ }^{10}$ with modification in the aliquots for the enzymatic solutions and determined using a spectrophotometer. 100 $\mu \mathrm{L}$ of a buffer ( $\mathrm{pH}$ 6.8), $100 \mu \mathrm{L}$ of the enzyme solution $(0.2$ units $\mathrm{mL}^{-1}$ ) and $50.0 \mu \mathrm{L}$ of each rice sample (extract) were added to each tube. The mix was incubated $37^{\circ} \mathrm{C}$ for $5 \mathrm{~min}$. The reaction started by adding $100 \mu \mathrm{L}$ of the substrate $(2.5$ mmol $\mathrm{L}^{-1}$ ). For the blank and control, the enzyme and the extract, respectively, were not added. After the incubation at $37^{\circ} \mathrm{C}$ for $30 \mathrm{~min}, 1000 \mu \mathrm{L}$ of Glycine solution $(0.200$ mol $\left.\mathrm{L}^{-1}\right)$ were added to each flask to stop the reaction. The quantity of p-nitrophenol ( $\mathrm{NNPG)}$ was measured using a spectrophotometer at $400 \mathrm{~nm}$.

\section{AC-inhibitory activity (ACE)}

For ACE determination, the methodology described by Goretta et al. ${ }^{11}$ was used, where $30 \mu \mathrm{L}$ of each sample was added to $200 \mu \mathrm{L}$ borate buffer and $60.0 \mu \mathrm{L}$ of $\mathrm{HCL}$ solution. The mix was incubated at $37^{\circ} \mathrm{C}$ for $10 \mathrm{~min}$. Then, $20.0 \mu \mathrm{L}$ was added to the enzymatic solution, where it was incubated again for 3 more minutes. After the enzymatic phase using the peptides, the reaction was stopped by adding $250 \mathrm{uL}$ of $\mathrm{HCl}$ solution $1.0 \mathrm{~mol} \mathrm{~L}^{-1}$. For organic separation, $1.7 \mathrm{~mL}$ of ethyl acetate afterward, $1.2 \mathrm{~mL}$ ethyl acetate was extracted and transferred to flasks, then the samples were submitted to a hot bath until the solvent evaporation was removed. The retained material was resuspended with $1 \mathrm{~mL}$ of deionized water and the quantification was performed using a spectrophotometer at $228 \mathrm{~nm}$.

\section{Statistical analysis}

All analyses were performed in triplicate and the results were expressed as means \pm standard deviation. The statistical analysis was determined by analysis of variance (ANOVA) and Tukey test $(p<0.05)$ using EXCEL 2018 (Version 1611) XLSTAT 2014.

\section{RESULTS \\ Physicochemical characterization}

There was a significative difference $(p<0.05)$ between the studied samples, regarding centesimal composition. The Virginia flour cultivar showed a higher concentration of proteins. Regarding lipid fraction, Rubi had the highest values, followed by the Pequeno and Virginia cultivar. As for ash and total carbohydates, Pequeno had the highest amounts. There were significant differences $(p<0.05)$ between samples with respect to resistant and water soluble starch, where the Rubi cultivar showed the highest resistant starch values and the Virginia cultivar had the highest value for digestable starch. There was not a significant difference $(p>0.05)$ with respect to the amylose and amylopectin proportion between the samples (Table 1). 
Table 1. Physicochemical characterization, antioxidant capacity, antihyperglycemic, antihypertensive properties of three red rice cultivars (Oryza sativa L.)

\begin{tabular}{|c|c|c|c|}
\hline & \multicolumn{2}{|c|}{ Red Rice } & \multirow{2}{*}{ Pequeno $^{1}$} \\
\hline & Nut & viाँाi। & \\
\hline \multicolumn{4}{|l|}{ Physicochemical characterization } \\
\hline Protein $\left(\mathrm{g} \mathrm{kg}^{-1}\right)$ & $110 \pm 0.170^{\mathrm{b}}$ & $124 \pm 0.210^{\mathrm{a}}$ & $101 \pm 0.110^{c}$ \\
\hline Lipids $\left(\mathrm{g} \mathrm{kg}^{-1}\right)$ & $44.8 \pm 0.110^{\mathrm{a}}$ & $41.3 \pm 0.103^{c}$ & $42.7 \pm 0.090^{b}$ \\
\hline Ash $\left(\mathrm{g} \mathrm{kg}^{-1}\right)$ & $18.4 \pm 0.080^{\mathrm{b}}$ & $16.1 \pm 0.070^{c}$ & $23.6 \pm 0.010^{\mathrm{a}}$ \\
\hline Total carbohydrates $\left(\mathrm{g} \mathrm{kg}^{-1}\right)$ & $826 \pm 0.600^{\mathrm{b}}$ & $818 \pm 1.60^{c}$ & $833 \pm 0.300^{\mathrm{a}}$ \\
\hline Total starch $\left(\mathrm{g} \mathrm{kg}^{-1}\right)$ & $528 \pm 0.300^{\mathrm{b}}$ & $536 \pm 0.900^{\mathrm{a}}$ & $521 \pm 0.400^{c}$ \\
\hline Hydrolyzed starch $\left(\mathrm{g} \mathrm{kg}^{-1}\right)$ & $395 \pm 0.190^{c}$ & $437 \pm 0.500^{\mathrm{a}}$ & $413 \pm 0.120^{b}$ \\
\hline Resistant Starch $\left(\mathrm{g} \mathrm{kg}^{-1}\right)$ & $133 \pm 1.20^{\mathrm{a}}$ & $98.0 \pm 1.50^{c}$ & $108 \pm 2.30^{\mathrm{b}}$ \\
\hline Amylose (\%) & $5.64 \pm 0.800^{\mathrm{a}}$ & $5.45 \pm 0.200^{\mathrm{a}}$ & $5.59 \pm 0.50^{\mathrm{a}}$ \\
\hline Amylopectin (\%) & $94.3 \pm 8.40^{\mathrm{a}}$ & $94.5 \pm 6.30^{\mathrm{a}}$ & $94.7 \pm 6.90^{\mathrm{a}}$ \\
\hline Non Starch Polysaccharides $\left(\mathrm{g} \mathrm{kg}^{-1}\right)$ & $298 \pm 0.700^{b}$ & $284 \pm 0.100^{c}$ & $312 \pm 0.800^{\mathrm{a}}$ \\
\hline \multicolumn{4}{|l|}{ Color parameters } \\
\hline$L^{*}$ & $75.9 \pm 0.900^{\mathrm{b}}$ & $77.7 \pm 0.200^{\mathrm{a}}$ & $75.4 \pm 1.03^{c}$ \\
\hline$a^{*}$ & $5.54 \pm 0.400^{\mathrm{a}}$ & $4.59 \pm 0.100^{b}$ & $5.98 \pm 0.300^{\mathrm{a}}$ \\
\hline$b^{*}$ & $9.90 \pm 0.100^{\mathrm{ab}}$ & $8.82 \pm 0.800^{\mathrm{b}}$ & $10.1 \pm 0.100^{\mathrm{a}}$ \\
\hline \multicolumn{4}{|l|}{ Antioxidant capacity } \\
\hline DPPH $\left(\mu \text { molTrolox Eq. } g^{-1}\right)^{2}$ & $21.0 \pm 2.10^{\mathrm{a}}$ & $10.2 \pm 3.20^{\mathrm{b}}$ & $22.9 \pm 2.70^{\mathrm{a}}$ \\
\hline FRAP $\left(\mu \mathrm{mol} \mathrm{Fe} \mathrm{g}^{-1}\right)^{3}$ & $72.4 \pm 2.00^{\mathrm{b}}$ & $70.8 \pm 1.80^{\mathrm{b}}$ & $109 \pm 3.90^{\mathrm{a}}$ \\
\hline Total phenolics (mg GAE g-1) & $0.550 \pm 0.820^{\mathrm{a}}$ & $0.520 \pm 0.160^{\mathrm{a}}$ & $0.610 \pm 0.130^{a}$ \\
\hline Proanthocyanidin (mgQuebracho Eq. $\mathrm{G}^{-1}$ ) & $0.870 \pm 0.010^{b}$ & $0.020 \pm 0.030^{c}$ & $2.14 \pm 0.060^{\mathrm{a}}$ \\
\hline \multicolumn{4}{|l|}{ Antihyperglycemic capacity } \\
\hline$\alpha$-amilase Inhibition (\%) & $56.7 \pm 0.100^{\mathrm{a}}$ & $67.2 \pm 0.10^{b}$ & $76.5 \pm 0.190^{c}$ \\
\hline$\alpha$-glucosidase Inhibition(\%) & $73.7 \pm 0.400^{b}$ & $81.0 \pm 0.23^{c}$ & $76.5 \pm 0.160^{\mathrm{a}}$ \\
\hline \multicolumn{4}{|l|}{ Antihypertensive capacity } \\
\hline ACE Inhibition $(\%)^{4}$ & $38.4 \pm 0.540^{\mathrm{a}}$ & $24.74 \pm 0.83^{b}$ & $34.7 \pm 0.760^{c}$ \\
\hline
\end{tabular}

${ }^{a-c}$ Different letters at the same line indicate significant differences between samples $(p<0.05) ;{ }^{1}$ Data are expressed as mean \pm standard deviation, dry weight; 3 replicates; ${ }^{2}$ radical scavenging activity 2,2-diphenyl-1-picryl-hydrazine; ${ }^{3}$ Ferric Reducing Antioxidant Power; ${ }^{4}$ Angiotensin Enzyme converter.

The rice cultivars presented significant differences $(p<0.05)$ in the non-starch carbohydrate content. The Pequeno cultivar had the highest values for non-starch carbohydrates followed by the Rubi and Virginia flours, respectively (Table 1).

\section{Color parameters}

There was a significant difference $(p<0.05)$ for $L^{*}$ - values (Table 1). Virgina flour had higher values than those from the Rubi and Pequeno cultivars, indicating an increased luminosity level of this cultivar. However, no significant 
difference ( $p>0.05$ ) between Rubi and Pequeno samples for the a* coordinator (Table 1) was observed, even though Virginia flour had shown significant differences when compared to the other flours for the same response. Regarding b* coordinator, which corresponds to the variation in the interval color from blue to yellow, Rubi did not differ statistically ( $p>0.05$ ) from the Pequeno and Virginia cultivars.

\section{Antioxidant capacity}

The Rubi and Pequeno flour samples showed higher scavenge capacity measured by DPPH and did not differ statistically ( $p>0.05$ ). For the FRAP method, the Pequeno flour culivar showed the best capacity to reduce Fe(III) compared to the other two cultivars that did not show a significant difference $(p>0.05)$. In the concentration of total phenolic, there was no differences ( $p>0.05$ ) between samples.

There was a significant difference in the concentration of proanthocyanidins between the samples (Table 1).

\section{The inhibition of $\alpha$-glucosidase and amylase}

Inhibition of $\alpha$-amylase and $\alpha$-glucosidase presented a significant difference $(p<0.05)$ between the three flour cultivars evaluated (Table 1). The samples presented a percentage that varied from 56.0 to $76.0 \%$ of inhibition of the $\alpha$-amylase enzyme.

\section{AC-inhibitory activity (ACE)}

Among the samples in the present study, we observed a significant difference $(p<0.05)$ between the studied samples with respect to ACE. However, the red rice cultivar (Rubi) showed the highest ACE followed by Virginia and Pequeno (Table 1).

\section{DISCUSSION}

The physical and chemical characteristics of red rice can be affected by the type of crop (Table 1) since the conditions of the culture can alter the chemical composition of the plant. The values we observed were higher than those of Kraithong, Lee and Rawdkuen ${ }^{4}$ that reported the mean value of $72.3 \mathrm{~g} \mathrm{~kg}^{-1}$ of protein for four cultivars of Thai organic red rice powder. Moreover, the values are also higher to those described by the $\mathrm{FAO}^{12}$ for red rice $(7.00 \%)$.

Variations in the protein content can be justified by the genetic characteristics of the plant and other factors such as the soil (nitrogen) and environmental conditions (solar radiation and temperature), among others. Protein quantity is determined by the quantity of the amino acid profile. Oliveira et al. ${ }^{5}$ evaluated the profile of amino acids and found 177; 90.2; $80.7 \mathrm{mg} \mathrm{g}^{-1}$ of glutamine, leucine, and arginine, respectively, in whole red rice powder.

Gunaratne ${ }^{13}$ found that the usual rice variety consumed (i.e., parboiled white polished rice) shows reduced content of amino acids when compared to the whole pigmented one, due to the proteins and amino acids that are present in the external layers, which during processing are removed.

Besides that, even though rice shows a reduced protein ratio, among other cereals, this macronutrient is the second most abundant component in the grain and has been used as an alternative to wheat, due to the increasing number of people that have some intolerance to gluten or those who have celiac disease. Rice protein is usually composed of globulins fractions, glutelins, and prolamins that are defined for their different solubilization solutions, such as salt, acid, and alkaline, respectively. From a technological perspective, these characteristics are important, since they interfere in the quality of the dough, as well as in the elasticity and resistance ${ }^{14}$.

The lipid content of the three cultivars varied between 41.3 to $44.8 \mathrm{~g} \mathrm{~kg}^{-1}$ (Table 1). These results were superior to those observed by Biswas et al. ${ }^{15}$ that reported the total lipid content of $21.0 \mathrm{~g} \mathrm{~kg}^{-1}$ for whole red rice, whereas, $38.8 \%$ were related to monounsaturated fatty acids and $37.23 \%$ polyunsaturated. Additionally, Somaratne ${ }^{16}$ also observed lower values (11.1 $\mathrm{g} \mathrm{kg}^{-1}$ and $\left.24.0 \mathrm{~g} \mathrm{~kg}^{-1}\right)$ in different samples of red rice when compared to the samples of this study.

According to Jeong, Kim, and Lee ${ }^{17}$, the lipid content of rice is present in cereal powder, which represents $10.0 \%$ of the whole grain and justifies the lipid proportion in this study since it represents whole cereals. This evidence can explain the lipid ratio in the samples of this study since it involves whole grains.

Chemically, lipid content in whole rice can be classified into saponifiable and unsaponifiable lipids. The former is constituted by triglyceride, diglycerides, monoacylglycerols, free fatty acids and waxes, while the latter is composed of sterols, tocopherols, tocotrienols, triterpene alcohols. Regarding whole red rice, around $50.0 \%$ of its lipid content is constituted of unsaponifiable lipids, especially by $\alpha$-oryzanol, which is associated with antioxidant capacity. It also plays a role in the prevention of cardiovascular diseases and in HDL increase ${ }^{18}$.

Regarding ash content, a variation from $16.1 \mathrm{~g} \mathrm{~kg}^{-1}$ to $23.6 \mathrm{~g} \mathrm{~kg}^{-1}$ was observed. These results are superior compared to those of Sompong ${ }^{19}$ that found values ranging from 8.20 to $15.0 \mathrm{~g} \mathrm{~kg}^{-1}$ among ten samples of red rice from different Asian countries.

The mineral content in whole rice is more expressive when compared to the polished variety, due to the micronutrients that are found in the grain pericarp. Shao ${ }^{2}$ evaluated concentrations of potassium, magnesium, manganese, zinc, iron, sodium and copper in five rice cultivars from China and observed mean values of potassium, magnesium, manganese of 2167; 1185; $3687 \mathrm{mg} \mathrm{kg}^{-1}$, respectively, among the samples of whole red rice studied.

The total carbohydrate results of this study were higher than those reported by Kraithong, Lee, and Rawdkuen ${ }^{4}$. These results were expected since a study showed that the mean carbohydrate proportion in the rice varied from 750 to $860 \mathrm{~g} \mathrm{~kg}^{-1}$ for both the whole grain and the whole pigmented one ${ }^{16}$.

Starch content in rice can vary due to environmental and genetic factors. The values were approximately $64.0 \%, 65.5$ 
and $62.6 \%$ of the total carbohydrates in the Rubi, Virginia and Pequeno cultivars, respectively. These percentual values were inferior to the ones observed by $\mathrm{Frei}^{7}$, who reported a starch content between 72.0 and $82.0 \%$ in whole rice from different cultivars.

Starch can be classified as rapidly digestible starch (RDS), slowly digestible starch (SDS), and resistant starch (RS). Each category has differences in the release and absorption of glucose. Digested starch is converted into glucose and becomes a source of energy in the human $\operatorname{diet}^{20}$. The rice samples showed a RS content of 98.0, 108 and $133 \mathrm{~g} \mathrm{~kg}^{-1}$ for Virginia, Pequeno and Ruby cultivars, respectively. These results are in accordance with the literature and they are available in matrices to the whole rice ${ }^{7,21,22}$. Determining the RS portion within the food is an important nutritional parameter to be considered since RS reaches the small intestine. Once the RS reaches the intestine, it is fermented and it breaks down by the microflora in short chain fatty acids. Fatty acids improve colon health by decreasing the $\mathrm{pH}$, inhibiting the growth of AGCCs promoting benefits to the colon by lowering its $\mathrm{pH}$, inhibiting the growth of sarcoplasmic agent, thus increasing the number of prebiotics in the gastrointestinal tract ${ }^{22}$.

With the increase of non-communicable chronic diseases, it has become more important to find food that can help to fulfill the necessity of meeting the daily portions of fiber (25.0-30.0 g) for healthy adults ${ }^{23}$. Compared to other values of RS observed in this study with a daily recommendation of fiber, it is estimated that an average portion $5.17 \mathrm{~g}$ of rice is capable to meet these requirements ${ }^{23}$.

The ratio of RS can also be influenced by a fraction of amylose and amylopectin in the native starch, since after the retrogradation process a rearrangement may occur. This rearrangement leads to an interaction between the amylose and amylopectin that makes the starch structure more resistant ${ }^{24}$.

Zhu et al. ${ }^{21}$ evaluated the digestibility of starch in four rice samples and found that the percentage of amylose varyied between $17.0 \%$ and $55.4 \%$. Authors observed that the proportion of RS directly related to amylose content.

Starch hydrolysis is proportionally associated with its accessibility to the digestive enzymes $\alpha$-amylase and $\alpha$-glucosidase, which depend on the surface area of the granule. Observing the results of the percentage of amylose and amylopectin of the studied rice (Table 1). it was possible to observe that both cultivars presented a low content of amylose, which was not expected since, in general, rice cereals present an average of 20.0-35.0\% of amylose.

Commercially, starch is classified according to amylose content. It is reduced when it has proportion less than $20 \%$ of amylose, intermediate $21.0-35.0 \%$ and high over $26.0 \%{ }^{25}$.

The starch with high amylose is known for its high resistance to digestion and consequently high content of RS. The concentration of amylose in the rice grains is directly correlated to the digestion rate of the starch, postprandial serum glucose and insulin response. The linear structure of amylose promotes a firm conformation of this structure, which make difficult the action of amylolytic enzymes ${ }^{20}$.

From a technological perspective, starch with high amylose content is of limited use to the industry due to its structural conformation: its non-solubilization in water, reduced tendency for retrogradation, and high syneresis ${ }^{25}$.

On the other hand, Jeong ${ }^{17}$ analyzed the effect of different proportions (12.0, 19.0 and 26.0\%) of amylose in white rice powder in the elaboration of gluten-free pasta. It was observed that when the amylose content was high, the dough became more firm and less elastic, which would make the dough difficult during cooking.

The elevated fraction of amylopectin interferes significantly in the quality of the pasta since the high-water absorption properties for amylopectin could reduce gluten development, which would lead to a sticky texture ${ }^{26}$.

The concentration of non-starchy carbohydrates in the cultivars studied corresponded to approximately $34.7-37.4 \%$ of total carbohydrates.

In whole rice, part of its non-starchy carbohydrates are classified as insoluble in relation to human digestion (e.g., cellulose, hemicellulose and lignin). Moreover, other components also correspond to intracellular soluble material (e.g., hemicellulose and pectin). These materials are synthesized by vegetables to play specific metabolites functions, such as gums and mucilage. The consumption of these fractions reduces the total energetic value of those whole grains and contributes significantly to the maintenance of human health ${ }^{4}$.

\section{Nutritional Aspects}

The portion recommendation suggested by the Food and Drug Administration whole rice is $140 \mathrm{~g}$. The total daily energy value suggested by the $\mathrm{WHO}$ is $2000 \mathrm{kcal}$ for a healthy adult and should be divided into $10.0-15.0 \%$ of protein, $25.0-35.0 \%$ of lipids and up to $60.0 \%$ of carbohydrates. To meet these requeriments, a carbohydrate amount of $38.6 \%$, 38.2 and $38.9 \%$, can be obtained by the consumption of $140 \mathrm{~g}$ of Rubi, Virginia, and Pequeno cultivars, respectively.

Among all the evaluated nutrients (i.e. protein, lipids and carbohydrates) in the samples of this study, only the protein content met daily recommendations. However, it was possible to observe that for each cultivar, Rubi, Virginia, and Pequeno represented 29.0; 29.0 and $29.1 \%$ of total energy values, respectively, for a portion of $140 \mathrm{~g}$ per day. These results were superior to those mentioned by $\mathrm{FAO}^{12}$, which showed that $100 \mathrm{~g}$ of non-pigmentated whole rice can provide $20 \%$ of energy and $15 \%$ of protein, which is essential for all individuals.

Kraithong, Lee, and Rawdkuen ${ }^{4}$ have shown that due to pigmentation, whole rice presents a greater fraction of macronutrients, such as protein and lipids. In addition, part of its carbohydrates is non-starch polysaccharides, which positively contributes to a reduction in total energy consumed.

According to Kennedy and Burlingame ${ }^{27}$, the consumption 
of white rice, both the white and pigmented rice produced in some parts of Asia represents more than half of the energetic source for its population. The consumption of $100 \mathrm{~g}$ of rice provides $84.7 \%$ of carbohydrates, $6.5 \%$ of protein and $3.7 \%$ of lipids.

\section{Color parameters}

The highest value of $L *$ for the Virginia cultivar was expected since it had a bigger grain and endosperm fraction, that could be visually noticed when compared to the other cultivars. Thus, the higher starch portion contributed to the luminosity interference within the samples. Anggraini et al. ${ }^{28}$ evaluated the color parameters for red rice powder and observed that significant changes between rice colors could be associated with phenolic content on each cultivar.

The most important coordinate for the studied rice was $\mathrm{a}^{*}$ because it corresponded to the color interval between red and green. The major pigment for this variety is due to proanthocyanidins, which confer red color to the grain (Table 1). The grains were fully milled; therefore, they presented different size for the endosperm portion, which may explain the observed differences.

On the other hand, among the three analyzed cultivars, the sample that had the highest $\mathrm{a}^{*}$ value was Pequeno followed by Rubi and Virginia. This result was expected since visually, Pequeno has a red color for its pericarp and endosperm.

Kraithong, Lee, and Rawdkuen ${ }^{4}$ evaluated red rice powder and observed 8.31 for the coordinate $\mathrm{a}^{*}$, a superior result to the ones observed in the studied samples (Table 1).

Regarding the $b^{*}$ values, Rubi, Virginia and Pequeno cultivar presented the following values: 9.90, 8.82 and 10.1 , respectively, which corresponded to a yellow color passing through blue to red. A significant difference in these parameters was expected, as well as in the a* coordinator, due to the presence of the phenolic compounds and the fact that the pigment has a direct relationship with $\mathrm{a}^{*}$ and $\mathrm{b}^{*}$ values. These compounds presented in the studied samples represent benefits to human health when compared to white rice powder ${ }^{28}$.

\section{Antioxidant capacity}

The observed results for the antioxidant capacity in the three red rice cultivars showed that these cereals presented promising performance over the DPPH and FRAP methods. The main bioactive compound related to DPPH scavenging capacity in red rice was the proanthocyanidins, which may present a varied concentration among plants due to many factors, such as soil type and conditions, genetic material, seasonality, and climatic condition ${ }^{28}$. Therefore, the variation in the values observed in the present study can be explained.

These results were superior to those of Sumczynski et al. ${ }^{29}$, who analyzed rice samples from France, Cambodia, and Thailand and observed values of 8.90, 13.9 and 14.7 $\mu \mathrm{mol}$ of Trolox Eq. $\mathrm{g}^{-1}$ in dry sample, respectively. The same was observed by Pang et al. ${ }^{30}$ and Shao et al. ${ }^{2}$ when they reported mean values of 2.98 and $2.41 \mu \mathrm{mol}$ of Trolox Eq. ${ }^{-1}$ of dry sample, respectively, in whole red rice samples evaluated.

The mean of $84.1 \mu \mathrm{mol} F \mathrm{Fe}^{\mathrm{llg}-1}$ of dry sample, between the three samples studied was 25 times higher than the mean of $3.25 \mu \mathrm{mol}$ of $\mathrm{Fe}^{\mathrm{Il}-1}$ in dry sample reported by Niu et al. ${ }^{26}$, who performed a comparative study of eleven red rice samples harvested at the same time of year, from the same harvest area, in 2006 and in 2007. The authors attributed the difference in the ferric reduction capacity to the variation of climatic and soil conditions. However, the mean value, $84.1 \mu \mathrm{mol}$ of $\mathrm{Fe}^{\mathrm{ll}-1}$ in dry sample was similar (85.0 $\mu \mathrm{mol}$ of Fe $\mathrm{F}^{\mathrm{ll}-1}$ of dry sample) to that observed by Sompong et al. ${ }^{19}$

The total phenolic concentrations presented in the three samples suggest a positive correlation with antioxidant capacity. Lower scores were observed by Pengkumsri et al. ${ }^{31}$ and Biswas et al..$^{15}$ in samples of red rice.

Ferulic, p-coumaric, isoferulic, vanillic, sinapic, caffeic, p-hydroxybenzoic and protocatechuic acids have been reported in rice ${ }^{29}$. Hu et al. ${ }^{32}$ identified phenolic acids by HPLC in samples of red rice and observed a major presence of gallic, ferulic and coumaric acids. The proanthocyanidins is a subclass of phenolics compounds, named condensed tannins, which is found in purple-red rice and other colored cereals. In red rice, these substances accumulate on the external layers that color the grain pericarp ${ }^{29}$.

Phenolic compounds benefit human health due to free radical scavenging ${ }^{33}$. Moreover, they are also associated to transcription and methylation of DNA, inducing the autophagocytosis of unnecessary intracellular material, which stimulates oxidative phosphorylation and modulates the redox state in the cells, contributing to the survival or apoptosis mechanism.

The proportion of proanthocyanidins $0.870,0.020$ and $2.14 \mathrm{mg}$ Quebracho Eq. $\mathrm{G}^{-1}$ in the Rubi, Virginia and Pequeno samples, respectively, were correlated to the $\mathrm{a}^{*}$ coordinator. This reaction was expected since the proanthocyanidins present in the pericarp confers a characteristic color to the cereal as showed by Chen McClung and Bergmam ${ }^{9}$.

The mean of $1.01 \mathrm{mg}$ Quebracho Eq.G ${ }^{-1}$ observed in this study was 9.42 times higher when compared to the one observed by Huang and $\mathrm{Lai}^{34}$ in six samples of rice bran. Chen, McClung and Bergman ${ }^{9}$ reported when comparing the proanthocyanidins presented in rice bran with its powder, the later value is significantly lower since rice powder contains $10.0 \%$ of bran, which explains the difference observed between the mean values found in this study.

\section{Inhibition of $\alpha$-glucosidase and amylase}

Inhibition of $\alpha$-amylase and $\alpha$-glucosidase is an important factor since it is related to glucose release from starch hydrolysis. The samples presented a percentage that varied from 56.7 to $76.5 \%$ of $\alpha$-amylase enzyme inhibition, which it is a good suppression of the enzyme since the test 
with acarbose (a commercial drug) presented $69.0 \%$ for $\alpha$-amylase and $75.0 \%$ for $\alpha$-glucosidase. Even though there are few studies showing the inhibitory effect of the enzyme by red rice, Tan et al. ${ }^{35}$ suggested that the proanthocyanidins present in vegetables can inhibit up to $80.0 \%$ of $\alpha$-amylase. In addition, its natural matrix can minimize the effects such abdominal distension caused by synthetic inhibitors (acarbose). Gonzalez et al. ${ }^{36}$ analyzed the relationship between different structures of flavonoids and its interaction with $\alpha$-amylase and suggested that the number of hydroxyl groups on its molecule could determine the inhibition activity of $\alpha$-amylase. Other studies verified that red rice presents an expressive amount of proanthocyanidins (i.e., flavonoids) that are classified by its carbon and hydroxyl groups $s^{35,27,13}$.

$\alpha$-glucosidase located in the intestine membrane cells can hydrolase oligosaccharides, releasing glucose, which is carried to the bloodstream. During the break down of proanthocyanidins, there is flavonoids formation, which is similar to the $\alpha$-glucosidase substrate. Therefore they compete in the active site by inactivating the enzymes ${ }^{37}$.

Tadera et al..$^{38}$ evaluated the inhibition effect of flavonoids over $\alpha$-glucosidase and $\alpha$-amylase and observed that a group of proanthocyanidins demonstrated an important percentage of inhibition over $\alpha$-glucosidase when compared to $\alpha$-amylase. Additionally, they reported that the more carbon rings the structure has the more its potential to inhibit the enzyme since the substrate mechanism takes place by competing its active site.

\section{AC-inhibitory activity (ACE)}

The angiotensin-converting enzyme is a hydrolase that plays an important role regulating blood pressure, not only to promote potent vasoconstriction from angiotensin II but also to catalyze the degradation of bradykinin, a peptide with hypotensive properties ${ }^{39}$.

There are few studies that report an association between ACE rate and red rice, however, it has been shown that the crop condition, weather and soil characteristics are important factors since they affect the phenolic compounds within the grain during ripening; therefore, affecting proanthocyanidins content as well. Goretta ${ }^{11}$ and collaborators reported that pigmented cereals rich in phenolic compounds can reduce blood pressure since they may act in ACE activity, not only in vivo but also in vitro. Taubert ${ }^{40}$ evaluated the blood pressure of elderly people for 14 days by giving them a regular diet rich in proanthocyanidins and found that blood pressure levels decreased. Authors associated the decreases to the tannins which affect ACE inhibition.

\section{CONCLUSION}

In conclusion, the whole rice powder from three red rice cultivars showed significant differences for all evaluated parameters. Regarding nutritional values, flours offered macronutrients concentrations that fulfill the recommended total energetic value according to the WHO. Moreover, part of the total carbohydrate was resistant starch, which develops the same function as fiber. Additionally, the Pequeno cultivar showed the best results with respect to antioxidant capacity and antihyperglycemic potential compared to the other cultivars, however, the Rubi and Virginia flours also demonstrated good potential for the same analysis. Thus, the flours evaluated can be classified as functional foods. The introduction of these powders may enhance the nutritional characteristics of foods.

Acknowledgments. This research was supported by the Federal Rural University of Rio de Janeiro (UFRRJ), the Post-Graduation Program in Food Science and Technology (PPGCTA), the National Council for Scientific, the Technological Development (CNPq), the Brazilian Agricultural Research Corporation (EMBRAPA), the Carlos Chagas Filho Foundation for Research Support of the State of Rio de Janeiro (FAPERJ) and the Coordination for the Improvement of Higher Education Personnel (CAPES). The authors also gratefully thank Prof Dr. Carlos Wanderlei Piler de Carvalho, from the Brazilian Agricultural Research Corporation (EMBRAPA) for all the support given to this study.

\section{REFERENCES}

1. Bouasla A, Wójtowicz A, Zidone MN. Gluten-free precooked rice pasta enriched with legumes flours: Physical properties, texture, sensory attributes and microstructure. LWT 2017; 75: 569-577.

2. Shao Y, Hu Z, Yu Y, Mou R, Zhu Z, Beta T. Phenolic acids, anthocyanins, proanthocyanidins, antioxidant activity, minerals and their correlations in non-pigmented, red, and black rice. Food Chem 2018; 239(15): 733-741.

3. Niu Y, Gao B, Slavin M, Zhang Z. Phytochemical compositions, and antioxidant and anti-inflammatory properties of twentytwo red rice samples grown in Zhejiang. LWT 2013; 54: 521-527.

4. Khraithong $S$, Lee $S$, Rawdkuen S. Physicochemical and functional properties of Thai organic rice flour. I Cereal Sci 2018; 79: 259-266.

5. Oliveira LC, Lima DCN, Bailoni Ma, Risso EM, Schmiele M, Steel CJ and Chang YK. Physical Characteristics, nutritional quality, and antioxidant potential of extrudates produced with polished rice, whole red bean flours. Cereal Chem 2017; 94(1): 74-81.

6. Association of official analytical chemists of the AOAC. 2010. 18th ed. Gaithersburg, Maryland.

7. Frei $M$, Siddhuraju P, Becker $K$. Studies on the in vitro starch digestibility and the glycemic index of six different indigenous rice cultivars from the Philippines. Food Chem, 2003; 83(3): 395-402.

8. Rufino MSM, Alves RE, Brito ES, Jiménez JP, Calixto FS, Mancini-Filho J. Bioactive compounds and antioxidant capacities of eighteen non-traditional tropical fruits from Brazil. Food Chem 2010; 121: 996-1002.

9. Chen $M H$, McClung A M, Bergman C J. Concentrations of oligomers and polymers of proanthocyanidins in red and purple rice bran and their relationships to total phenolics, flavonoids, antioxidant capacity and whole grain color. Food Chem 2016; 208(1): 279-287. 
10. Lavelli V, Sri Harsha PSC, Ferranti P. Scarafoni A, lametti S. Grape skin phenolics as inhibitors of mammalian $\alpha$-g/ucosidase and $\alpha$-amylase - effect of food matrix and processing on efficacy. Food Funct, 2016; 7(3): 1655-1663.

11. Goretta, LA, Ottaviani IL, Keen CL, Fraga CG. Inhibition of angiotensin converting enzyme (ACE) activity by avan-3-ols and procyanidins. FEBS Lett, 2003; 555(3): 597-600.

12. Food and Agriculture Organization of the united nations (FAO). Statistical year book. World food and agriculture Roma. 2013, 307 p. Acesso em: 19/01/2017. Disponível em: http://www.fao.org/3/a-i5555.pdf

13. Gunaratne A, Wu K, Li D, Bentota A, Corke H, Cai YZ. Antioxidant activity and nutritional quality of traditional red-grained rice varieties containing proanthocyanidins. Food Chem 2013; 138(2-3): 1153-116.

14. Balindong, IL, Ward RM, Liu L, Rose TJ, Pallas LA. Rice grain protein composition influences instrumental measures of rice cooking and eating quality. I Cereal Sci 2018; 79: 35-42.

15. Biswas SK, Kim DE, Keum YS, Saini RK, Metabolite profiling and antioxidante activities of white, red, and black rice (Oryza sativa L.) grains. I Food Measu Charact 2018; 12: 2484-2492.

16. Somaratne GM, Prasantha BDR, Dunuwila GR, Chandrasekara A, Wijesinghe DGNG, Gunasekara DCS. Effect of polishing on glycemic index and antioxidant properties of red and white basmati rice. Food Chem 2017; 237(15): 716-723.

17. Jeong S, Kim HG, Lee S. Rheological and secondary structural characterization of rice flour-zein composites for noodles slit from gluten-free sheeted dough. Food Chem 2017; 221(15): 1539-1545.

18. Ternero CP, Sotomayor MA, Herrera MD. Contribution of ferulic acid, $\gamma$-oryzanol and tocotrienols to the cardiometabolic protective effects of rice bran. I Funct Foods 2017; 32: 5871.

19. Sompong, R, Ehn SS, Martin GL, Berghofer E, Physicochemical and antioxidative properties of red and black rice varieties from Thailand, China and Sri Lanka. Food Chem 2011; 124(1): 132-140.

20. Kumar A, Sahoo U, Baisakha B, Oko A, Resistant starch could be decisive in determining the glycemic index of rice cultivars. J Cereal Sci 2018; 79: 348-353.

21. Zhu J, Zhang S, Zhang B, Qiao D, Pu H, Liu S, Li L. Structural features and thermal property of propionylated starches with different amylose/amylopectin ratio. Int I Biolog Macrom 2017; 97: 123-130.

22. Gani A, Ashar BA, Akhter G, Shah A, Wani IA, Masoodi FA. Physico-chemical, structural, pasting and thermal properties of starches of fourteen Himalayan rice cultivars. Int J Biolog Macrom 2017; 95: 1101-1107.

23. BRAZIL. Ministry of Agriculture. Normative Instruction $n^{\circ} 06$ de 16 de fev. de 2009. 211/5000 Rice Technical Regulation, defining its official classification standard, with identity and quality requirements, sampling, mode of presentation and marking or labeling. Official Diary of the Union.17 de fevereiro de 2009. Seção 1, p

24. Raigond $P$, Ezekiel $R$, Raigond B. Resistant starch in food: a review. J Sci Food Agric 2015; 95(10): 1968-1978.
25. Oh IK, Bae IY, Lee HG. Hypoglycemic Effect of Dry Heat Treated Starch With Xanthan: An In Vitro and In Vivo Comparative Study. Starch-Stärke 2018; 70: 9-10.

26. Niu M, Hou GG, Zhao S. Dough rheological properties and noodle-making performance of non-waxy and waxy whole-wheat flour blends. J Cereal Sci 2017; 75: 261-268.

27. Kennedy G, Burlingame B. Analysis of food composition data on rice from a plant genetic resources perspective. Food Chem 2003; 80(4): 589-596.

28. Anggraini T, Limber NU, Amelia R. Antioxidant activities of some red, black and white rice cultivar from west Sumatra, Indonesia. Pakistan I Nut 2015; 14(2): 112-117.

29. Sumczynnski D, Kotásková E, Druzbíková H, Micek J. Determination of contentes and antioxidant activity of free and bound phenolic compounds and in vitro digestibility of commercial black and red rice (orysa sativa L.) varieties. Food Chem 2016; (211): 339-346.

30. Pang Y, Ahmed S, Xu Y, Beta T, Zhu Z, Shao Y, Bao J. Bound phenolic compounds and antioxidant properties of whole grain and bran of white, red and black rice. Food Chem 2018; 240(1): 212-221.

31. Pengkumsri N, Chaiyasut C, Saenjum C, Sirilun S, Peerajan S, Suwannalert $P$, Sirisatha S, Sivamaruthi BS. Physicochemical and antioxidative properties of black, brown and red rice varieties of northern Thailand. Food Sci Tech 2015; 35(2): 331-338.

32. Hu Z, Tang X, Liu J, Zhu Z, Shao Y. Effect of parboiling on phytochemical content, antioxidant activity and physicochemical properties of germinated red rice. Food Chem 2017; 214(1): 285-292.

33. Kim H, Quon MJ, Kim J. New insights into mechanisms of polyphenols beyond antioxidant properties; lessons from the green tea polyphenol, epigallocatechin 3-gallate. Redox Biol 2014; 2: 187-195.

34. Huang YP, Lai HM. Bioactive compounds and antioxidative activity of colored rice bran. I of Food Drug Analysis 2016; 24(3): 564-574.

35. Tan Y, Chang SKC, Zhang Y. Comparison of a-amylase, a-glucosidase and lipase inhibitory activity of the phenolic substances in two black legumes of different genera. Food Chem 2017; 214: 259-268.

36. Gonzalez ALM, Sánchez AGD, Rosa LAI, Jaimes $L B$, Parrilla $E A$. Inhibition of $\alpha$-amylase by flavonoids: Structure activity relationship (SAR). Spectrochimica Acta Mol Biomol SpectrosC 2019; 206(5): 437-447.

37. Derosa G, Maffoli P. $\alpha$-Glucosidase inhibitors and their use in clinical practice. Arch Med Sci 2012; 8(5): 899-906.

38. Tadera K, Minami Y, Takamatsu K, Matsuoka T. Inhibition of $\alpha$-Glucosidase and $\alpha$-Amylase by Flavonoids. I Nutr Sci Vitaminol 2006; 52(2): 149-153.

39. Polesi LF, Sarmento SBS, Brazaca SGC. Starch Digestibility and Functional Properties of Rice Starch Subjected to Gamma Radiation. Rice Sci 2018; 25(1): 42-51.

40. kjdl Taubert D, Breitenbach T, Lazer A, Censarek P, Harlfinger $S$, Berkels $R$, Klaus $W$, Roesen $R$. Reaction rate constants of superoxide scavenging by plant antioxidants. Free Radic Biol Med 2003; 35(12): 1599-1607. 